\title{
ANALISIS KINERJA KEUANGAN MENGGUNAKAN METODE ECONOMIC VALUE ADDED
}

\section{Ratih Juwita $^{1}$, Mochamad Rafli ${ }^{2}$, Antoni $^{3}$}

Universitas Gunadarma

Email: ratih_j@staff.gunadarma.ac.id ${ }^{1}$, mocrafli@student.gunadarma.ac.id ${ }^{2}$, antoni@staff.gunadarma.ac.id ${ }^{3}$

\section{Abstrak}

Latar belakang: Economic Value Added (EVA) merupakan pengukuran kinerja berdasarkan nilai tambah ekonomis yang dihasilkan oleh perusahaan sebagai akibat dari aktivitas atau strategi manajemen. Perusahaan pembiayaan, sebagai perusahaan yang menyewakan, menyediakan dana serta produk yang diperlukan, tidak menarik dana dari konsumen dan mengalami perkembangan yang relatif cepat. PT Wahana Ottomitra Multiartha, Tbk salah satu yang terus berkembang di Indonesia.

Tujuan penelitian: Penulisan ilmiah ini bertujuan untuk menganalisis kinerja keuangan meggunakan metode Economic Value Added (EVA) (Studi Empiris Pada PT Wahana Ottomitra Multiartha, Tbk).

Metode penelitian: Metode yang digunakan adalah dengan melakukan studi pustaka dan mengunduh laporan keuangan PT Wahana Ottomitra Multiartha, Tbk tahun 2016-2020. Jenis data yang digunakan pada penulisan ilmiah ini adalah jenis data kuantitatif karena penulisan ilmiah ini menggunakan data berupa angka yaitu, laporan keuangan PT Wahana Ottomitra Multiartha, Tbk.

Hasil penelitian: Hasil penulisan ilmiah ini menunjukkan bahwa pengukuran kinerja keuangan PT Wahana Ottomitra Multiartha, Tbk meggunakan metode Economic Value Added (EVA) pada periode 2016-2020 masih belum mampu menghasilkan nilai tambah ekonomis karena Economic Value Added (EVA) bersifat negatif karena nilai Net Operating Profit After Tax (NOPAT) lebih kecil daripada Capital Charges.

Kesimpulan: Kinerja keuangan PT Wahana Ottomitra Multiartha, Tbk meggunakan metode Economic Value Added (EVA) pada periode 2016-2020 masih belum mampu menghasilkan nilai tambah ekonomis karena Economic Value Added bersifat negatif disebabkan karena Net Operating Profit After Tax (NOPAT) merupakan laba yang diperoleh setelah pajak perusahaan lebih kecil daripada Capital Charges merupakan biaya yang harus dibayarkan kepada investor perusahaan dari setiap tahunnya.

Kata kunci: Economic Value Added (EVA), Laporan Keuangan, Kinerja Keuangan

\section{Abstract}

Background: Economic Value Added (EVA) is a performance measurement based on the added economic value generated by the company as a result of management activities or strategies. A finance company, as a leasing company, provides the necessary funds and products, does not attract funds from consumers and is experiencing relatively fast development. PT Wahana Ottomitra Multiartha, Tbk is one that continues to grow in Indonesia..

The purpose of the study: Scientific writing aims to analyze financial performance using the Economic Value Added (EVA) method (Empirical Study at PT Wahana Ottomitra Multiartha, Tbk).

Research method: The method used is to do a literature study and download the financial statements of PT Wahana Ottomitra Multiartha, Tbk for 2016-2020. The type of data used in scientific writing is quantitative data because scientific writing uses data in the form of numbers, namely, the financial statements of PT Wahana Ottomitra Multiartha, Tbk.

The results of the study: The results of this scientific writing indicate that the measurement of the financial performance of PT Wahana Ottomitra Multiartha, Tbk using the Economic Value Added (EVA) method in the 2016-2020 period is still not able to generate economic added value because the Economic Value Added (EVA) is negative because the value of Net

\begin{tabular}{ll}
\hline & Ratih Juwita, Mochamad Rafli, Antoni. (2021). Analisis Kinerja Keuangan Menggunakan \\
& Metode Economic Value Added. Co-Value: Jurnal Ekonomi, Koperasi Kewirausahaan \\
How to cite: & Vol12(2): $65-74$ \\
E-ISSN: & https://greenpublisher.id/ \\
Published by: & L
\end{tabular}


Operating Profit After Tax (NOPAT) is smaller than Capital Charges.

Conclusion: The financial performance of PT Wahana Ottomitra Multiartha, Tbk using the Economic Value Added (EVA) method in the 2016-2020 period is still not able to generate economic added value because the Economic Value Added is negative because Net Operating Profit After Tax (NOPAT) is profit earned after tax company is smaller than Capital Charges are fees that must be paid to the company's investors from each year.

Keywords: Economic Value Added (EVA), Financial Statements, Financial Performance

Diterima: 26-06-2021; Direvisi: 6-07-2021; Disetujui: 6-07-2021

\section{PENDAHULUAN}

Perusahaan pembiayaan, sebagai perusahaan yang menyewakan, menyediakan dana serta produk yang diperlukan, tidak menarik dana dari konsumen dan mengalami perkembangan yang relatif cepat.(Diani, 2020) PT Wahana Ottomitra Multiartha, Tbk salah satu yang terus berkembang di Indonesia.(Utami, 2021) Perusahaan ini disibukkan dengan aktivitas pembiayaan sepeda motor sehingga membuat perusahaan ini terus berkembang. Perusahaan ini menjadi salah satu yang terbaik di bidang pembiayaan.(Richad, 2020) Memiliki aset sebesar Rp. 5-10 Triliun serta sudah menerima predikat Best-Performing Multifinance. Akan tetapi, perusahaan ini mengalami penurunan pendapatan yang sangat besar di tahun 2020 yaitu sebesar 24,2\% dibandingkan dengan perusahaan sejenis lainnya seperti PT Maybank Indonesia Finance 1,88\%, PT Sinar Mas Multifinance 5,66\%, PT Buana Finance, Tbk 18,95\%, dan PT Mandala Multifinance 10,57\%.

Tabel 1 Pendapatan PT Wahana Ottomitra Multiartha, Tbk

\begin{tabular}{cc}
\hline Tahun & Pendapatan \\
\hline 2016 & 1.927 .885 \\
2017 & 2.154 .431 \\
2018 & 2.616 .114 \\
2019 & 2.643 .687 \\
2020 & 2.000 .850 \\
\hline
\end{tabular}

Sumber : Laporan Keuangan PT Wahana Ottomitra Multiartha, Tbk

Berdasarkan laporan keuangan PT Wahana Ottomitra Multiartha, Tbk periode 2016-2020 perusahaan mengalami berfluktuasi, akan tetapi terjadi penurunan tajam pada tahun 2020. Peningkatan yang cukup signifikan terjadi pada tahun 2018 karena sepanjang tahun perusahaan memiliki peningkatan terhadap kontribusinya dari jasa pembiayaan multiguna, perbaikan strategi collection, dan penerapan grading untuk meningkatkan kualitas pembiayaan. PT Wahana Ottomitra Multiartha, Tbk juga terus memperkuat sumber pendanaan melalui program pinjaman bank dan penerbitan obligasi berkelanjutan.(saldi Ahmad et al., 2019) Berkat perbaikan dan strategi bisnis yang dijalankan dengan baik, berdampak pada pertumbuhan kinerja dengan peningkatan pendapatan perseroan sebesar 21,4\% dibandingkan tahun sebelumnya.(Hardianti, 2018) Akan tetapi, pada tahun 2020 pendapatan perseroan turun sebesar $24,2 \%$ akibat dampak dari pandemi virus COVID-19 dan penting bagi perusahaan untuk menjaga kinerja keuangan dalam posisi yang meningkat.

\section{METODE PENELITIAN}

Objek yang menjadi dasar dalam penelitian ini adalah PT Wahana Ottomitra Multiartha, Tbk. PT Wahana Ottomitra Multiartha, Tbk bergerak di bidang pembiayaan 
sepeda motor khususnya merek Honda. PT Wahana Ottomitra Multiartha berlokasi di Jl. Yos Sudarso Kav 85, RT.9/RW.11, Sunter Jaya, Tanjung Priok, Jakarta Utara, Jakarta 14360.(NOVIA, 2020)

Jenis data yang digunakan pada penulisan ilmiah ini adalah jenis data kuantitatif karena penulisan ilmiah ini menggunakan data berupa angka yaitu, laporan keuangan PT Wahana Ottomitra Multiartha, Tbk.(Utami, 2021) Sumber data pada penulisan ilmiah ini adalah data sekunder, yaitu laporan keuangan PT Wahana Ottomitra Multiartha, Tbk tahun 2016-2020.(Mulyana, 2020)

Teknik pengumpulan data dalam penelitian ini studi pustaka, yaitu pengumpulan data dengan mengadakan studi penelaah terhadap buku, literatur, catatan, dan laporan yang ada hubungannya dengan masalah yang dipecahkan. Teknik ini digunakan untuk memperoleh dasar-dasar dan pendapat secara tertulis yang dilakukan dengan cara mempelajari berbagai literatur yang berhubungan dengan masalah yang diteliti.(BAGUS SANTOSO, 2021) Data penelitian ini berupa informasi keuangan, yaitu laporan laba rugi perusahaan selama periode 2016-2020.(Reinaldy, 2021) Selain menggunakan laporan keuangan, pengumpulan data juga menggunakan buku dan jurnal yang terkait penelitian.

Berikut adalah buku dan jurnal yang penulis jadikan sebagai referensi dalam penulisan ilmiah ini:

1.Analisis Kinerja Keuangan Perusahaan.

2.Praktis Menyusun Laporan Keuangan.

3.Manajemen Keuangan dan Bisnis Teori dan Aplikasi.

4.Jurnal Riset Akuntansi \& Bisnis.

5.Jurnal Tangibel.

6.Jurnal Jurnal Rekayasa Keuangan, Syariah, dan Audit.

7.Jurnal Ekonomi, Manajemen, Bisnis, dan Akuntansi.

8.Jurnal Ilmu Manajemen dan Akuntansi Terapan.

Teknik analisis yang digunakan dalam penulisan ilmiah ini adalah teknik analisis deskriptif kuantitatif., yaitu analisis data dengan cara mendiskripsikan atau menggambarkan data yang telah terkumpul sebagaimana adanya tanpa bermaksud membuat kesimpulan yang berlaku untuk umum.(Octaviani \& Sutriani, 2019) Dalam penulisan ilmiah alat analisis yang digunakan adalah Economic Value Added (EVA). Berikut ini tahapan perhitungan Economic Value Added (EVA):

1.Menghitung Net Operating Profit After Tax (NOPAT)

2.Menghitung Invested Capital (IC)

$$
N O P A T=E A T+\text { Biaya Bunga }
$$

$I C=$ Total Hutang \& Ekuitas - Hutang Jangka Pendek

3. Menghitung Weighted Average Cost of Capital (WACC)

a. Tingkat modal dari hutang (D) diketahui dari perbandingan antara total hutang dengan jumlah hutang dan ekuitas, yang dirumuskan sebagai berikut:

$$
D=\frac{\text { Total Hutang }}{\text { Total Hutang dan Ekuitas }} \times 100 \%
$$

b. Biaya Hutang (Cost of Debt (rd)) diketahui dari perbandingan antara biaya bunga dengan total hutang, yang dirumuskan sebagai berikut:

$$
r d=\frac{\text { Biaya Bunga }}{\text { Total Hutang Jangka Panjang }} \times 100 \%
$$

c. Tingkat Modal dan Ekuitas (E) diketahui dari perbandingan antara total ekuitas dan jumlah hutang dan ekuitas, yang dirumuskan sebagai berikut: 


$$
E=\frac{\text { Total Ekuitas }}{\text { Total Hutang dan Ekuitas }} \times 100 \%
$$

d. Biaya Ekuitas (Cost of Equity (re)) diketahui dari perbandingan antara laba per saham dengan harga saham, yang dirumuskan sebagai berikut:

$$
r e=\frac{\text { Laba per lembar saham }}{\text { Harga Saham }} \times 100 \%
$$

e. Tingkat Pajak (T) diketahui dari perbandingan beban pajak dengan laba bersih sebelum pajak, yang dirumuskan sebagai berikut:

f.

$$
T=\frac{\text { Beban Pajak }}{\text { Laba Bersih Sebelum Pajak }} \times 100 \%
$$

g. $\quad$ Menghitung WACC dengan rumus:

$$
W A C C=(D \times r d) \times(1-T)+(E x r e)
$$

4. Menghitung Capital Charges (CC)

5. Menghitung Economic Value Added (EVA)

$$
C C=\text { WACC } \mathrm{x} \text { Invested Capital }
$$$$
E V A=\text { NOPAT }- \text { Capital Charge }
$$

\section{HASIL DAN PEMBAHASAN}

\section{Net Operating Profit After Tax (NOPAT)}

Menurut Endang (2016:36) Net Operating Profit After Tax (NOPAT) pada dasarnya merupakan tingkat keuntungan yang diperoleh dari modal yang ditanam.(Kurnia Cindy Resi, 2020)

Tabel 2 Hasil Perhitungan NOPAT (Dalam Jutaan Rupiah)

\begin{tabular}{cccc}
\hline \multirow{2}{*}{ Tahun } & Laba Bersih Setelah Pajak & Biaya Bunga & NOPAT \\
\hline 2016 & 60,303 & 1,544 & 61,847 \\
2017 & 180,665 & 2,295 & 182,960 \\
2018 & 215,183 & 1,753 & 216,936 \\
2019 & 259,671 & 2,727 & 262,398 \\
2020 & 57,378 & 3,160 & 60,538 \\
\hline
\end{tabular}

Sumber: Data Diolah 2021

NOPAT paling tinggi pada tahun 2019 sebesar Rp. Rp. 262.398.000.000 yang disebabkan karena peningkatan laba bersih yang mencapai Rp. 259.671.000.000 dan biaya bunga yang mencapai Rp. 2.727.000.000 NOPAT paling rendah pada tahun 2020 sebesar Rp. 60.538.000.000 yang disebabkan karena penurunan laba bersih sebesar Rp. 57.378.000.000 dan biaya bunga sebesar Rp. 3.160.000.000 Rata-rata NOPAT perusahaan periode 2016-2020 adalah sebesar Rp. 156.936.000.000

\section{Invested Capital}

Menurut Endang (2016:36) Invested Capital (IC) merupakan hasil penjabaran perkiraan dalam neraca untuk melihat besarnya modal yang diinvestasikan perusahaan 
oleh kreditur dan seberapa besar modal yang di investasikan dalam perusahaan.(Hefrizal, 2018)

Tabel 3 Hasil Perhitungan Invested Capital (IC) (Dalam Jutaan Rupiah)

\begin{tabular}{cccc}
\hline Tahun & $\begin{array}{c}\text { Total Hutang dan } \\
\text { Ekuitas }\end{array}$ & $\begin{array}{c}\text { Hutang Jangka } \\
\text { Pendek }\end{array}$ & IC \\
\hline 2016 & $6,670,916$ & 178,010 & $6,492,906$ \\
2017 & $7,745,732$ & 99,022 & $7,646,710$ \\
2018 & $8,827,307$ & 99,207 & $8,728,100$ \\
2019 & $8,271,170$ & 131,900 & $8,139,270$ \\
2020 & $5,283,702$ & 43,034 & $5,240,668$ \\
\hline
\end{tabular}

Sumber: Data Diolah 2021

Invested Capital paling tinggi yang dicapai perusahaan adalah pada tahun 2018 sebesar Rp. 8.728.100.000.000 yang disebabkan karena total hutang dan ekuitas mencapai Rp. 8.827.307.000.000 dan hutang jangka pendek mencapai Rp. 99.207.000.000. Dan Invested Capital paling rendah pada tahun 2020 yang disebabkan karena total hutang dan ekuitas yang hanya Rp. 5.283.702.000.000 dan total hutang jangka pendek sebesar Rp. 43.034.000.000. Rata-rata Invested Capital perusahaan periode 2016-2020 adalah sebesar Rp. 7.213.131.000.000.

\section{Tingkat Modal dan Hutang (D)}

Tingkat modal dari hutang (D) diketahui dari perbandingan antara total hutang dengan jumlah hutang dan ekuitas

Tabel 4 Hasil Perhitungan Tingkat Modal dari Hutang (D) (Dalam Jutaan Rupiah)

\begin{tabular}{cccc}
\hline Tahun & Total Hutang & $\begin{array}{c}\text { Total Hutang } \\
\text { dan Ekuitas }\end{array}$ & D \\
\hline 2016 & $5,855,617$ & $6,670,916$ & $87 \%$ \\
2017 & $6,755,920$ & $7,745,732$ & $87 \%$ \\
2018 & $7,655,646$ & $8,827,307$ & $98 \%$ \\
2019 & $6,900,593$ & $8,271,170$ & $78 \%$ \\
2020 & $4,070,357$ & $5,283,702$ & $77 \%$ \\
\hline
\end{tabular}

Sumber: Data Diolah 2021

Tingkat modal dan hutang (D) paling tinggi yang dicapai perusahaan adalah pada tahun 2018 sebesar 98\% yang disebabkan karena total hutang mencapai Rp. 7.655.646.000.000 dan total hutang dan ekuitas sebesar Rp 8.827.307.000.000. Dan tingkat modal dan hutang (D) paling rendah pada tahun 2020 sebesar $77 \%$ yang disebabkan karena total hutang mencapai Rp. 4.070.357.000.000 dan total hutang dan ekuitas sebesar Rp. 5,283,702,000. Rata-rata tingkat modal dan hutang (D) perusahaan periode 2016-2020 adalah sebesar 85,40\%.

\section{Biaya Hutang (rd)}

Biaya Hutang (Cost of Debt (rd)) diketahui dari perbandingan antara beban bunga dengan total hutang jangka panjang. 
Analisis Kinerja Keuangan Menggunakan Metode e-ISSN: 2809-8862

Tabel 5 Hasil Perhitungan Cost of Debt (rd) (Dalam Jutaan Rupiah)

\begin{tabular}{cccc} 
Tahun & Biaya Bunga & $\begin{array}{c}\text { Total Hutang } \\
\text { Jangka Panjang }\end{array}$ & rd \\
\hline 2016 & 1,544 & $6,577,607$ & $0.02 \%$ \\
2017 & 2,295 & $6,656,898$ & $0.03 \%$ \\
2018 & 1,753 & $7,556,439$ & $0.02 \%$ \\
2019 & 2,727 & $6,768,693$ & $0.04 \%$ \\
2020 & 3,160 & $4,027,323$ & $0.08 \%$ \\
\hline
\end{tabular}

Sumber: Data Diolah 2021

Biaya hutang (rd) paling tinggi yang dicapai perusahaan adalah pada tahun 2020 sebesar 0,08\% yang disebabkan karena biaya bunga mencapai Rp. 3.160.000.000 dan total hutang jangka panjang sebesar Rp. 4.027.323.000.000. Dan biaya hutang (rd) paling rendah pada tahun 2016 dan 2018 sebesar 0,02\% karena biaya bunga pada tahun 2016 sebesar Rp. 1.544.000.000 dan 2018 sebesar Rp. 1.753.000.000. Sedangkan total hutang jangka panjang pada tahun 2016 sebesar Rp. 6.577.607.000.000 dan pada tahun 2018 sebesar Rp. 7.556.439.000.000 Rata-rata biaya hutang (rd) perusahaan periode 2016-2020 adalah sebesar $0,04 \%$.

\section{Modal dan Ekuitas (E)}

Tingkat Modal dan Ekuitas (E) diketahui dari perbandingan antara total ekuitas dan jumlah hutang dan ekuitas

Tabel 6 Hasil Perhitungan Modal dan Ekuitas (E) (Dalam Jutaan Rupiah)

\begin{tabular}{cccc}
\hline Tahun & $\begin{array}{c}\text { Total } \\
\text { Ekuitas }\end{array}$ & $\begin{array}{c}\text { Total Hutang } \\
\text { dan Ekuitas }\end{array}$ & E \\
\hline 2016 & 815,299 & $6,670,916$ & $12.22 \%$ \\
2017 & 989,812 & $7,745,732$ & $12.78 \%$ \\
2018 & $1,171,661$ & $8,827,307$ & $13.27 \%$ \\
2019 & $1,379,577$ & $8,271,170$ & $16.68 \%$ \\
2020 & $1,213,345$ & $5,283,702$ & $22.96 \%$ \\
\hline
\end{tabular}

Sumber: Data Diolah 2021

Modal dan ekuitas (E) paling tinggi yang dicapai perusahaan adalah pada tahun 2020 sebesar 22,96\% yang disebabkan karena total ekuitas mencapai Rp. 1.213.345.000.000 dan total hutang dan ekuitas sebesar Rp. 5.283.702.000.000. Dan modal dan ekuitas (E) paling rendah pada tahun 2016 sebesar 12,22\% yang disebabkan karena total ekuitas sebesar Rp. 815.299.000.000 dan total hutang dan ekuitas sebesar Rp. 6.679.916.000.000 Rata-rata modal dan ekuitas (E) perusahaan periode 2016-2020 adalah sebesar $15,58 \%$.

\section{Biaya Ekuitas (re)}

Biaya Ekuitas (Cost of Equity (re)) diketahui dari perbandingan antara laba lembar per saham dengan harga saham. 
Vol. 12, No. 2, pp. 65-74, Juli, 2021

Tabel 7 Hasil Perhitungan Cost of Equity (re) (Dalam Satuan Rupiah)

\begin{tabular}{cccc}
\hline Tahun & $\begin{array}{c}\text { Laba Per Lembar } \\
\text { Saham }\end{array}$ & Harga Saham & re \\
\hline 2016 & 17.32 & 131 & $13.22 \%$ \\
2017 & 51.89 & 196 & $26.47 \%$ \\
2018 & 61.81 & 312 & $19.81 \%$ \\
2019 & 74.59 & 278 & $26.83 \%$ \\
2020 & 16.48 & 278 & $5.93 \%$ \\
\hline
\end{tabular}

Sumber: Data Diolah 2021

Biaya ekuitas (re) paling tinggi yang dicapai perusahaan adalah pada tahun 2019 sebesar 26,83\% yang disebabkan karena laba per lembar saham mencapai Rp.74.59 dan harga saham sebesar 278. Dan biaya ekuitas (re) paling rendah pada tahun 2020 sebesar 5,93\% yang disebabkan karena laba per lembar saham sebesar Rp. 16.48 dan harga saham sebesar 278. Rata-rata biaya ekuitas (E) perusahaan periode 2016-2020 adalah sebesar $18,45 \%$.

\section{Tingkat Pajak (T)} pajak

Tingkat Pajak (T) diketahui dari perbandingan beban pajak dengan laba sebelum

Tabel 8 Hasil Perhitungan Tingkat Pajak (T) (Dalam Jutaan Rupiah)

\begin{tabular}{cccc}
\hline Tahun & Beban Pajak & $\begin{array}{c}\text { Laba Sebelum } \\
\text { Pajak }\end{array}$ & T \\
\hline 2016 & 4,319 & 34,676 & $12.46 \%$ \\
2017 & 4,291 & 241,752 & $1.77 \%$ \\
2018 & 3,743 & 287,163 & $1.30 \%$ \\
2019 & 7,125 & 371,066 & $1.92 \%$ \\
2020 & 6,681 & 93,955 & $7.11 \%$ \\
\hline
\end{tabular}

Sumber: Data Diolah 2021

Tingkat pajak $(\mathrm{T})$ paling tinggi yang dicapai perusahaan adalah pada tahun 2016 sebesar 12,46\% yang disebabkan karena beban pajak mencapai Rp. 4.319.000.000 dan laba sebelum pajak sebesar Rp. 34.676.000.000 Dan tingkat pajak (T) paling rendah pada tahun 2018 sebesar 1,30\% yang disebabkan karena beban pajak sebesar Rp. 3.743.000.000 dan laba sebelum pajak sebesar Rp. 287.163.000.000. Rata-rata tingkat pajak (T) perusahaan periode 2016-2020 adalah sebesar 4,9\%.

\section{Weighted Average Cost of Capital (WACC)}

Menurut Young Endang (2016:36) Weighted Average Cost of Capital (WACC) sama dengan jumlah biaya dari setiap komponen modal hutang jangka pendek, hutang jangka panjang, dan ekuitas pemegang saham ditimbang berdasarkan proporsi relatifnya dalam struktur modal perusahaan pada nilai pasar.(Hefrizal, 2018)

Tabel 9 Hasil Perhitungan Weighted Average Cost of Capital (WACC) (Dalam Jutaan Rupiah)

\begin{tabular}{lllllll}
\hline Tahun & D & rd & T & E & re & WACC
\end{tabular}


Analisis Kinerja Keuangan Menggunakan Metode e-ISSN: 2809-8862

\begin{tabular}{ccccccc}
\hline Tahun & D & rd & T & E & re & WACC \\
\hline 2016 & $87 \%$ & $0.02 \%$ & $12.46 \%$ & $12.22 \%$ & $13.22 \%$ & $1.64 \%$ \\
2017 & $87 \%$ & $0.03 \%$ & $1.77 \%$ & $12.78 \%$ & $26.47 \%$ & $3.42 \%$ \\
2018 & $98 \%$ & $0.02 \%$ & $1.30 \%$ & $13.27 \%$ & $19.81 \%$ & $2.66 \%$ \\
2019 & $78 \%$ & $0.04 \%$ & $1.92 \%$ & $16.68 \%$ & $26.83 \%$ & $4.52 \%$ \\
2020 & $77 \%$ & $0.08 \%$ & $7.11 \%$ & $22.96 \%$ & $5.93 \%$ & $1.42 \%$
\end{tabular}

Sumber: Data Diolah 2021

WACC paling tinggi yang dicapai perusahaan adalah pada tahun 2019 sebesar $4,52 \%$ yang disebabkan karena tingkat modal dan hutang (D) sebesar $78 \%$, biaya hutang (rd) sebesar 0,04\%, modal dan ekuitas (E) sebesar 16,68\%, biaya ekuitas (re) sebesar $26,83 \%$, dan tingkat pajak (T) sebesar 1,92\%. Dan WACC paling rendah pada tahun 2020 sebesar $1,42 \%$ yang disebabkan karena tingkat modal dan hutang (D) sebesar $77 \%$, biaya hutang (rd) sebesar 0,08\%, modal dan ekuitas (E) sebesar 22,96\%, biaya ekuitas (re) sebesar $5,93 \%$, dan tingkat pajak (T) sebesar 7,11\%. Rata-rata WACC perusahaan periode 2016-2020 adalah sebesar 2,73\%.(Murtianto et al., 2021)

\section{Capital Charges (CC)}

Menurut Endang (2016:36) Capital Charges (CC) merupakan aliran kas yang dibutuhkan untuk mengganti para investor atas risiko usaha dari modal yang ditanam.(Longdong \& Tawas, 2021)

Tabel 10 Hasil Perhitungan Capital Charges (CC) (Dalam Jutaan Rupiah)

\begin{tabular}{cccc}
\hline Tahun & IC & WACC & CC \\
\hline 2016 & $6,492,906$ & $1.64 \%$ & 106,437 \\
2017 & $7,646,710$ & $3.42 \%$ & 261,666 \\
2018 & $8,728,100$ & $2.66 \%$ & 231,812 \\
2019 & $8,139,270$ & $4.52 \%$ & 368,106 \\
2020 & $5,240,668$ & $1.42 \%$ & 74,417 \\
\hline
\end{tabular}

Sumber: Data Diolah 2021

Capital Charges paling tinggi yang dicapai perusahaan adalah pada tahun 2019 sebesar Rp. 368.106.000.000 yang disebabkan karena Invested Capital mencapai Rp. 8.139.270.000.000 dan WACC sebesar 4,52\%. Dan Capital Charges paling rendah pada tahun 2020 sebesar Rp. 74.417.000.000 yang disebabkan karena Invested Capital sebesar Rp. 5.240.668.000 dan WACC sebesar 1,42\%. Rata-rata Invested Capital perusahaan periode 2016-2020 adalah sebesar Rp. 208.488.000.000.

\section{Economic Value Added (EVA)}

Menurut Endang (2016:35) perusahaan apabila memiliki nilai EVA positif, maka dapat dikatakan bahwa manajemen perusahaan tersebut mampu menciptakan nilai tambah bagi perusahaannya.(Lombogia et al., 2021) Sebaliknya apabila EVA negatif, maka perusahaan mengalami distructing/ destroying value.

Tabel 11 Hasil Perhitungan Economic Value Added (EVA) (Dalam Jutaan Rupiah)

\begin{tabular}{cccc}
\hline Tahun & NOPAT & CC & EVA \\
\hline 2016 & 61,847 & 106,437 & $(44,590)$ \\
2017 & 182,960 & 261,666 & $(78,706)$
\end{tabular}


Vol. 12, No. 2, pp. 65-74, Juli, 2021

\begin{tabular}{cccc}
\hline Tahun & NOPAT & CC & EVA \\
\hline 2018 & 216,936 & 231,812 & $(14,876)$ \\
2019 & 262,398 & 368,106 & $(105,708)$ \\
2020 & 60,538 & 74,417 & $(13,879)$ \\
\hline
\end{tabular}

Sumber: Data Diolah 2021

EVA paling tinggi yang dicapai perusahaan adalah pada tahun 2018 sebesar Rp. 15.762.000.000 yang disebabkan karena NOPAT mencapai Rp. 216.936.000 dan Capital Charges sebesar Rp. 231.812.000.000. Dan EVA paling rendah perusahaan pada tahun 2019 sebesar Rp. -105.708.000.000 yang disebabkan karena NOPAT sebesar Rp. 262.398.000.000 dan Capital Charges sebesar Rp. 368.106.000.000. Rata-rata EVA perusahaan periode 2016-2020 adalah sebesar Rp. -51.928.000.000. Karena EVA < 0 maka dikatahan bahwa kinerja perusahaan tidak baik.

\section{KESIMPULAN}

Kinerja keuangan PT Wahana Ottomitra Multiartha, Tbk meggunakan metode Economic Value Added (EVA) pada periode 2016-2020 masih belum mampu menghasilkan nilai tambah ekonomis karena Economic Value Added bersifat negatif disebabkan karena Net Operating Profit After Tax (NOPAT) merupakan laba yang diperoleh setelah pajak perusahaan lebih kecil daripada Capital Charges merupakan biaya yang harus dibayarkan kepada investor perusahaan dari setiap tahunnya. Net Operating Profit After Tax (NOPAT) harus lebih besar daripada Capital Charges karena apabila laba yang diperoleh tinggi maka PT Wahana Ottomitra Multiartha, Tbk mampu membayar investasi kepada pihak investor.

\section{BIBLIOGRAFI}

BAGUS SANTOSO, S. (2021). TINGKAT KETEPATAN WAKTU (ON TIME PERFORMANCE) PADA MASKAPAI GARUDA INDONESIA DAN CITILINK DI BANDAR UDARA TJILIK RIWUT PALANGKA RAYA. STTKD Sekolah Tinggi Teknologi Kedirgantaraan Yogyakarta.

Diani, T. M. (2020). TINJAUAN HUKUM ISLAM TERHADAP IMPLEMENTASI PERATURAN MENTERI KEUANGAN NOMOR 84/PMK. 012/2006 TENTANG PERUSAHAAN PEMBIAYAAN PADA LARANGAN PEMBIAYAAN KONSUMEN DALAM BENTUK DANA TUNAI (Studi Pada Lembaga Pembiayaan Federal International Finance (FIF) Cabang Bandar Lampung. UIN Raden Intan Lampung.

Hardianti, D. (2018). Analisis perbandingan kinerja keuangan bank umum konvensional dan bank umum syariah berdasarkan rasio keuangan bank (studi pada bank umum konvensional dan bank umum syariah yang terdaftar dan diawasi oleh Otoritas Jasa Keuangan (OJK) periode 2013-2016). Universitas Brawijaya.

Hefrizal, M. (2018). Analisis metode economic value added untuk menilai kinerja keuangan pada PT. Unilever Indonesia. JURNAL AKUNTANSI DAN BISNIS: Jurnal Program Studi Akuntansi, 4(1). 
Analisis Kinerja Keuangan Menggunakan Metode e-ISSN: 2809-8862

Kurnia Cindy Resi, M. (2020). ANALISIS DU PONT SYSTEM DAN METODE ECONOMIC VALUE ADDED (EVA) UNTUK MENILAI KINERJA KEUANGAN PERUSAHAAN (Studi Pada PT Unilever Indonesia Tbk dan PT Indofood Sukses Makmur Tbk Periode 2016-2018). STIE MALANGKUCECWARA.

Lombogia, J. R. L., Malau, Y. N., \& Rosadi, F. (2021). Analisis pengaruh economic value added (EVA), capital structure, total assets turnover dan current ratio terhadap kinerja keuangan pada perusahaan sektor industri dasar dan kimia yang terdaftar di BEI pada Tahun 2017-2019. Jurnal Paradigma Ekonomika, 16(3), $517-526$.

Longdong, N. G. F., \& Tawas, H. N. (2021). ANALISIS ECONOMIC VALUE ADDED (EVA) DAN MARKET VALUE ADDED (MVA) SEBAGAI ALAT PENGUKUR KINERJA KEUANGAN PADA PT INDOFOOD SUKSES MAKMUR TBK. Jurnal EMBA: Jurnal Riset Ekonomi, Manajemen, Bisnis Dan Akuntansi, 9(4), 1153-1164.

Mulyana, E. R. (2020). Pengaruh Corporate Governance Dan Kualitas Audit Terhadap Agresivitas Pajak (Studi Empiris Pada Perusahaan Yang Terdaftar Di Bursa Efek Indonesia Tahun 2018). Universitas Brawijaya.

Murtianto, A., Akbar, M. T., \& Hendriyeni, N. S. (2021). Nilai Perusahaan pada Struktur Modal Optimal PT. Trans Marga Jateng dan PT. Jasamarga Surabaya Mojokerto Tahun 2020. Journal of Management and Business Review, 18(2), 343-364.

NOVIA, A. (2020). PENGARUH KURS DAN RISIKO PASAR TERHADAP RETURN SAHAM (Studi Pada Perusahaan Finance Yang Terdaftar di Bursa Efek Indonesia Periode 2016-2018). UNIVERSITAS WIJAYA PUTRA.

Octaviani, R., \& Sutriani, E. (2019). Analisis Data dan Pengecekan Keabsahan Data.

Reinaldy, I. (2021). PENGARUH DEWAN DIREKSI, KOMPENSASI MANAJERIAL, TOTAL ACCRUAL, DAN DEWAN KOMISARIS TERHADAP MANAJEMEN LABA PADA PERUSAHAAN MANUFAKTUR YANG TERDAFTAR DI BURSA EFEK INDONESIA (BEI) TAHUN 2016-2020. Sekolah Tinggi Ilmu Ekonomi Indonesia.

Richad, V. (2020). ANALISIS STRATEGI KEUNGGULAN BERSAING YANG DITERAPKAN PT. FEDERAL INTERNATIONAL FINANCE MENURUT PERSPEKTIF ETIKA BISNIS ISLAM. UIN Raden Intan Lampung.

saldi Ahmad, A., Bone, H., \& Kusumawardani, A. (2019). Pengaruh struktur modal terhadap kinerja keuangan pada perusahaan pembiayaan yang terdaftar di bursa efek indonesia 2011-2016. Jurnal Ilmu Akuntansi Mulawarman (JIAM), 3(4).

Utami, B. C. P. (2021). Analisis Kinerja Keuangan pada PT Wahana Ottomitra Multiartha Tbk di Masa Pandemi Covid 19. Jurnal Sistem Informasi Akuntansi (JASIKA), $1(1), 61-66$.

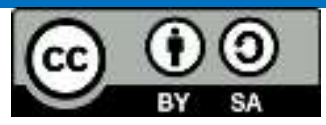

This work is licensed under a Creative Commons Attribution-ShareAlike 4.0 International License 